\title{
Case Series of Pleomorphic Carcinoma of the Lung Treated With Immune Checkpoint Inhibitors
}

\author{
KANA HAYASHI ${ }^{1}$, KOTARO TOKUI $^{1}$, MINEHIKO INOMATA $^{1}$, KENJI AZECHI ${ }^{1}$, ISAMI MIZUSHIMA ${ }^{1}$, \\ NAOKI TAKATA ${ }^{1}$, CHIHIRO TAKA $^{1}$, SEISUKE OKAZAWA ${ }^{1}$, KENTA KAMBARA $^{1}$, SHINGO IMANISHI ${ }^{1}$, \\ TOSHIRO MIWA ${ }^{1}$, RYUJI HAYASHI ${ }^{2}$, SHOKO MATSUI $^{1}$, SATOSHI NOMURA ${ }^{3}$ and KAZUYUKI TOBE ${ }^{1}$ \\ ${ }^{1}$ First Department of Internal Medicine, Toyama University Hospital, Toyama, Japan; \\ ${ }^{2}$ Department of Medical Oncology, Toyama University Hospital, Toyama, Japan; \\ ${ }^{3}$ Respiratory Medicine, Toyama City Hospital, Toyama, Japan
}

\begin{abstract}
Aim: We report, herein, three cases of pleomorphic carcinoma of the lung treated with immune checkpoint inhibitors. Case 1: A 73-year-old man was diagnosed as having pleomorphic carcinoma of the lung and treated with pembrolizumab alone. However, he showed no response and died 4 months after the initiation of the treatment. Case 2: A 66-year-old man was diagnosed as having pleomorphic carcinoma of the lung. He was started on a combination regimen of pembrolizumab plus carboplatin plus nabpaclitaxel, and a remarkable response was observed. Case 3: A 49-year-old man was diagnosed as having pleomorphic carcinoma of the lung. He was started on pembrolizumab monotherapy as second-line treatment. Eleven months after the treatment initiation, computed tomography revealed the decrease of tumor diameter. Conclusion: Immune checkpoint inhibitor therapy is expected to improve the prognosis of patients with pleomorphic carcinoma of the lung.
\end{abstract}

Pleomorphic carcinoma of the lung is one of the histological subtypes of sarcomatoid carcinoma, accounting for less than $1 \%$ of all cases of lung cancer (1). The response rate to cytotoxic agents is low, and the prognosis of patients with this type of cancer is poor (2-4). Recently, treatment with immune checkpoint inhibitors, administered either as monotherapy (5) or in combination with cytotoxic agents (6, 7 ), was demonstrated to be beneficial for patients with non-

This article is freely accessible online.

Correspondence to: Minehiko Inomata, MD, Ph.D., First Department of Internal Medicine, Toyama University Hospital, Sugitani 2630, Toyama 930-0194, Japan. Tel: +81 764347287, Fax: +81 764345025, e-mail: 9446-tym@umin.org

Key Words: Immune checkpoint inhibitor, pembrolizumab, pleomorphic carcinoma, sarcomatoid carcinoma. small-cell lung cancer. Herein, we report the clinical courses of three patients with pleomorphic carcinoma of the lung who were treated with immune checkpoint inhibitors, either as monotherapy, or in combination with cytotoxic agents.

\section{Case Reports}

This case series is a part of a clinical study approved by the Ethics Committee, University of Toyama (approved number: R2020099), and we disclosed to patients about using clinical information and publication, in accordance with Ethical Guideline for Medical and Health Research Involving Human Subjects (Ministry of Health, Labour and Welfare, Japan).

Case 1. A 73-year-old man was referred to our hospital because of tumors in the left lower lobe of the lung and small intestine. His Eastern Cooperative Oncology Group performance status was good (PS 1). However, during the clinical course, he developed obstructive pneumonia and ileus, and underwent surgical resection of the left lower lobe and resection of the affected segment of the small intestine. Histopathological examination of the resected specimens revealed the diagnosis of pleomorphic carcinoma of the lung (cT4N0M1a, stage IVA) with smallintestinal metastasis. The tumors were negative for driver mutations, including of epidermal growth factor receptor $(E G F R)$, ALK receptor tyrosine kinase $(A L K)$, and ROS proto-oncogene 1 , receptor tyrosine kinase $(R O S 1)$ but tumor programmed cell death 1 ligand 1 (PD-L1) expression, as assessed using 22C3 antibody, was positive [tumor proportion score (TPS): 80\%-90\%].

Pleural dissemination and abdominal subcutaneous metastasis became apparent after surgery (Figure 1A). Radiation therapy (45 Gy/25 fr) was administered for the abdominal lesion, and pembrolizumab monotherapy was initiated at the dose of $200 \mathrm{mg} /$ day. No response was 

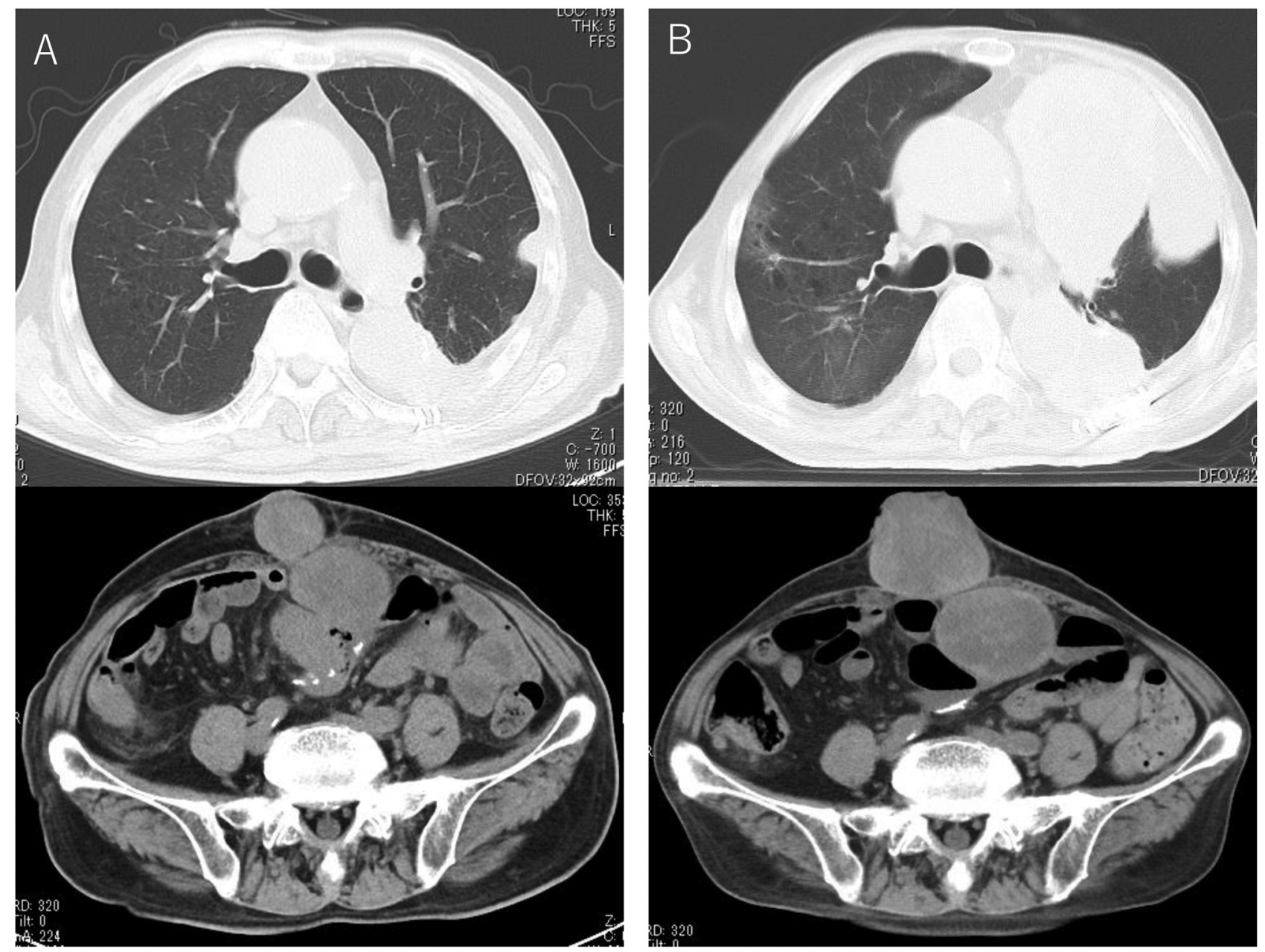

Figure 1. A: After surgical resection of the left lower lobe of the lung and involved segment of the small intestine, computed tomography showing pleural dissemination and abdominal subcutaneous metastasis in case 1. B: Computed tomography showing progression of the pleural dissemination and abdominal subcutaneous metastatic lesions after two cycles of pembrolizumab monotherapy. Upper and lower panels show pulmonary and abdominal lesions.

observed at the assessment conducted after two cycles of the therapy (Figure 1B), and the patient died 4 months after the initiation of pembrolizumab treatment.

Case 2. A 66-year-old man was admitted to a neighborhood hospital complaining of wheezing and breathlessness. Chest computed tomography revealed obstructive pneumonia due to a tumor in the left lung (Figure 2A). He was treated with antibiotics, and histopathological examination of a surgical biopsy of the tumor in the left lung revealed the diagnosis of pleomorphic carcinoma of the lung (cT4N2M0, stage IIIA). The tumor was negative for driver mutations, including of EGFR, $A L K$, and ROSI but tumor PD-L1 expression was positive (TPS: 90-100\%). Combined therapy with pembrolizumab (200 $\mathrm{mg}$ /day), carboplatin (area under the curve: 6, day 1), and nab- paclitaxel $\left(100 \mathrm{mg} / \mathrm{m}^{2}\right.$; days 1,8 , and 15$)$ was initiated, and follow-up examination revealed tumor shrinkage. He was transferred to our hospital for treatment continuation.

His performance status was 0 . After four cycles of the combination therapy, remarkable response was observed (Figure 2B), and maintenance treatment with pembrolizumab was still ongoing at 7 months after treatment initiation.

Case 3. A 49-year-old man visited a neighborhood hospital complaining of breathlessness, palpitations, and fever. Chest and abdominal computed tomography revealed tumors in the right upper lobe of the lung and right adrenal gland. Due to the rapid growth of the tumor in the right adrenal gland, surgical resection of the right adrenal gland was performed, and histopathological examination of the resected specimen 

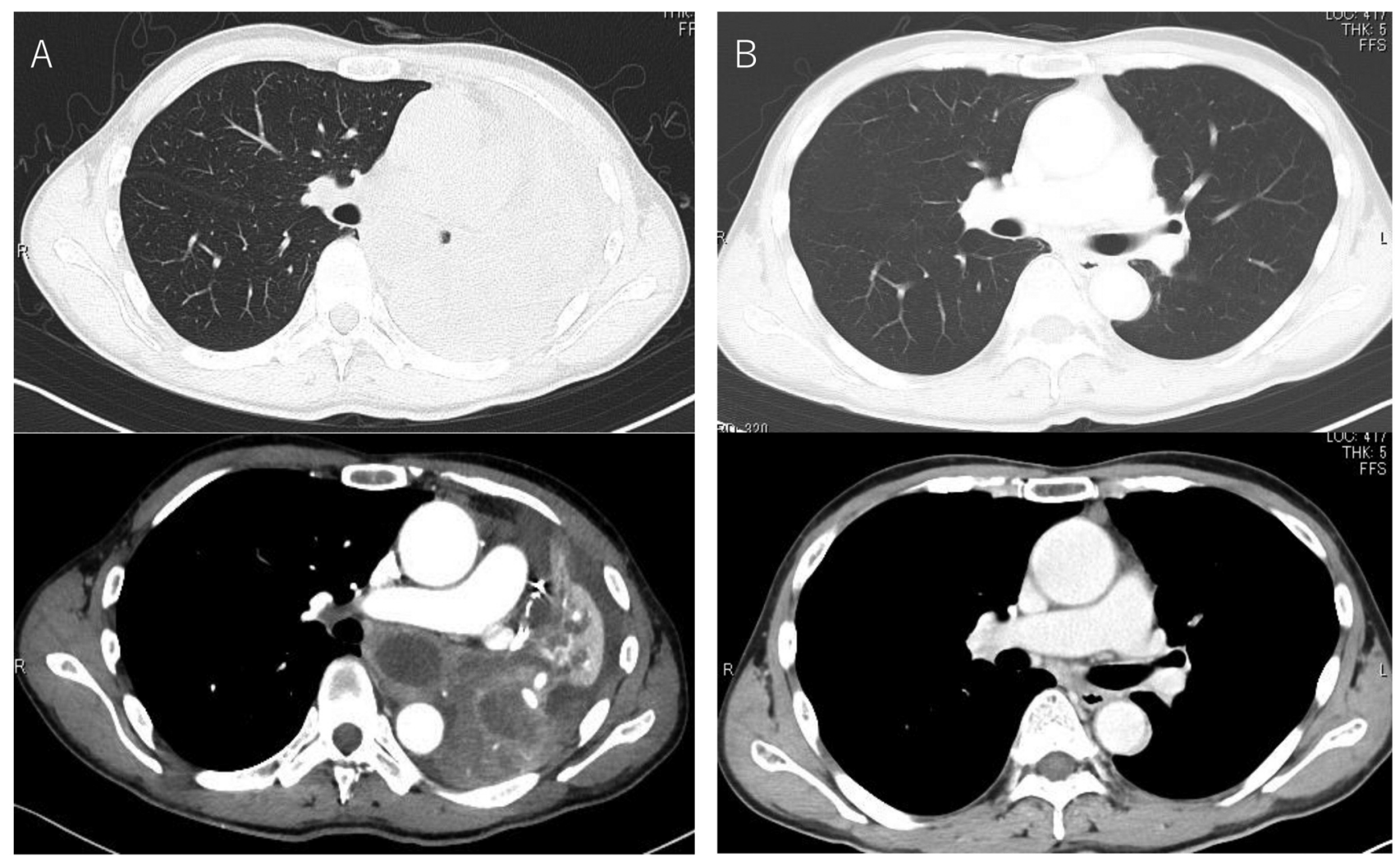

Figure 2. A: Computed tomography at first presentation of case 2 revealed a massive tumor in the left lower lobe and atelectasis and obstructive pneumonia of the left lower lobe. B: A decrease in size of the massive tumor in the left lower lobe was found on computed tomography after four cycles of combination therapy with pembrolizumab plus carboplatin and nab-paclitaxel. Upper and lower panels show pulmonary and mediastinal window settings.

revealed the diagnosis of pleomorphic carcinoma. He was then referred to our hospital for the purpose of systemic treatment.

He was diagnosed at our hospital as also having pleomorphic carcinoma of the lung (cT3N0M1b, stage IVA). Although his performance status was good (PS 1), the tumor in the right upper lobe showed rapid growth and a new tumor appeared in the left adrenal gland. Systemic chemotherapy was initiated with carboplatin (area under the curve: 6, day 1) plus nab-paclitaxel (100 mg/m $\mathrm{m}^{2}$; days 1,8 , and 15) and four cycles were administered. However, the primary tumor showed progression and bone metastases appeared, necessitating radiation therapy for the bone lesions (30 $\mathrm{Gy} / 10 \mathrm{fr}$ ). The tumors were negative for driver mutations of EGFR, ALK, ROS1, and BRAF but tumor PD-L1 expression was strongly positive (TPS: $60 \%-70 \%)$. Next-generation sequencing (Foundation One) revealed mutations of $B R C A 2$, RBM10, and TP53 genes but no actionable gene mutations, and a high tumor mutation burden (42 mutations/Mb). Pembrolizumab monotherapy was initiated at the dose of 200 $\mathrm{mg}$ /day. Assessment at 11 months after the initiation of treatment revealed the decrease of tumor diameter (Figure
3). Pembrolizumab therapy was still ongoing at 12 months after the initiation of treatment.

\section{Discussion}

We have presented three cases of pleomorphic carcinoma of the lung that were treated with immune checkpoint inhibitors, administered either as monotherapy or in combination with cytotoxic agents. Two patients, including one who received pembrolizumab monotherapy and one who received pembrolizumab in combination with cytotoxic agents, showed long survival, while the third patient who received pembrolizumab monotherapy failed to show any response to the immune checkpoint inhibitor therapy.

While the response to cytotoxic agents is reported to be poor in patients with pleomorphic carcinoma of the lung (2$4)$, there have been several reports of cases treated successfully with immune checkpoint inhibitors (8-12). Although publication bias should be considered, immune checkpoint inhibitors are expected to be effective against pleomorphic carcinoma of the lung. 

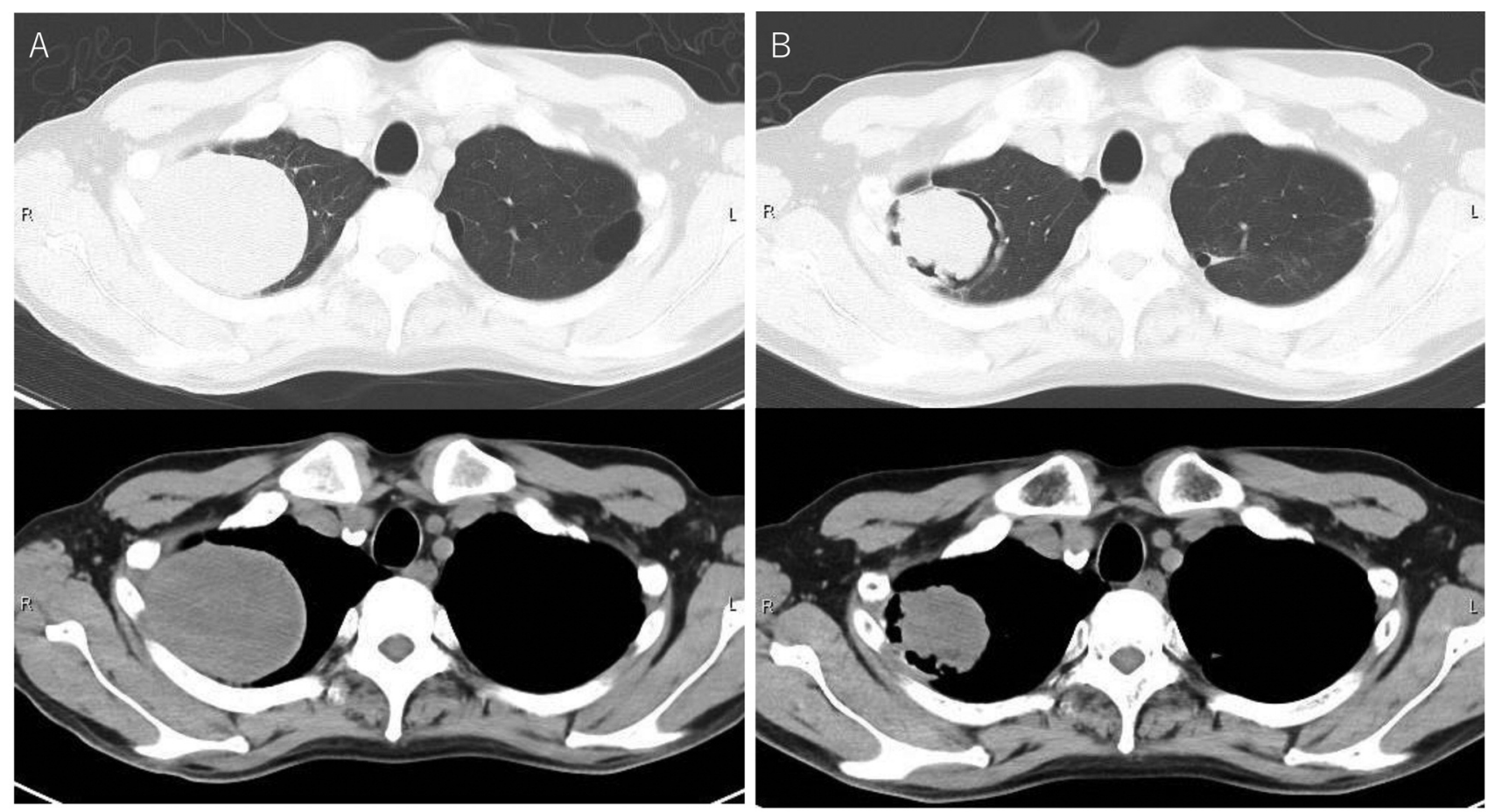

Figure 3. A: Computed tomography showing a tumor in the right upper lobe. B: A decrease of the tumor diameter was found on computed tomography at 11 months after the initiation of treatment. Upper and lower panels show pulmonary and mediastinal window settings.

The efficacy of immune checkpoint inhibitors in patients with non-squamous cell non-small cell lung cancer (13) is associated with PD-L1 expression, but this is not the case in patients with squamous cell non-small-cell lung cancer (14). Tumor PD-L1 expression is reported to be frequently positive in pleomorphic carcinoma of the lung $(15,16)$, especially in the sarcomatoid component (16). One retrospective analysis showed an association between positive tumor PD-L1 expression and longer survival after the initiation of immune checkpoint inhibitor therapy (17), suggesting that tumor PD-L1 expression may be a favorable biomarker of the efficacy of immune checkpoint inhibitor therapy in patients with pleomorphic carcinoma of the lung.

On the other hand, although all three cases showed positive tumor PD-L1 expression, one patient failed to show any response to pembrolizumab monotherapy. Kanazu et al. also reported similar observations in cases treated with nivolumab (8). These findings suggest that predictive factors other than tumor PD-L1 expression may exist for the response to immune checkpoint inhibitor therapy in patients with pleomorphic carcinoma of the lung. Tumor mutation burden (18), peripheral immune cell phenotypes, including the presence of BCL2 like $11(\mathrm{BIM})^{+} \mathrm{PD} 1^{+} \mathrm{CD} 8^{+} \mathrm{T}$-cells (19), PD-L $1^{+} \mathrm{CD} 11 \mathrm{~b}^{+}$cells (20), $\mathrm{PD}^{+}{ }^{+} \mathrm{CD} 4^{+} \mathrm{T}$-cells $(21), \mathrm{CD} 62 \mathrm{~L}^{\text {low }} \mathrm{CD} 4^{+} \mathrm{T}$-cells (22), PD$\mathrm{L} 1{ }^{+} \mathrm{CD} 14^{+}$monocytes (23), and clinical parameters, including the serum levels of lactate dehydrogenase, the neutrophil/lymphocyte ratio and serum C-reactive protein (2427), have been investigated as possible predictors of the efficacy of immune checkpoint inhibitor therapy in patients with non-small-cell lung cancer. However, there is as yet no clear evidence of the association between these factors and the clinical benefit of immune checkpoint inhibitor therapy in patients with pleomorphic carcinoma of the lung.

In conclusion, although pleomorphic carcinoma of the lung is refractory to cytotoxic agents, immune checkpoint inhibitors are expected to improve the prognosis of patients with this disease. Development of predictive biomarkers for the efficacy of immune checkpoint inhibitor therapy in patients with pleomorphic carcinoma of the lung is desired.

\section{Conflicts of Interest}

All Authors declare that they have no conflicts of interest.

\section{Authors' Contributions}

$\mathrm{KH}$ and $\mathrm{MI}$ contributed to preparation of the article. KH, K Tokui, KA, IM, NT, CT, SO, KK, SI, TM, RH, and SN were involved in medical treatment. SM and $\mathrm{K}$ Tobe reviewed the final version of the article. 


\section{References}

1 Travis WD, Brambilla E, Nicholson AG, Yatabe Y, Austin JHM, Beasley MB, Chirieac LR, Dacic S, Duhig E, Flieder DB, Geisinger K, Hirsch FR, Ishikawa Y, Kerr KM, Noguchi M, Pelosi G, Powell CA, Tsao MS, Wistuba I and WHO Panel: The 2015 World Health Organization classification of lung tumors: Impact of genetic, clinical and radiologic advances since the 2004 classification. J Thorac Oncol 10(9): 1243-1260, 2015. PMID: 26291008. DOI: 10.1097/JTO.0000000000000630

2 Bae HM, Min HS, Lee SH, Kim DW, Chung DH, Lee JS, Kim YW and Heo DS: Palliative chemotherapy for pulmonary pleomorphic carcinoma. Lung Cancer 58(1): 112-115, 2007. PMID: 17574296. DOI: 10.1016/j.lungcan.2007.05.006

3 Hong JY, Choi MK, Uhm JE, Park MJ, Lee J, Park YH, Ahn JS, Park K, Han JH and Ahn MJ: The role of palliative chemotherapy for advanced pulmonary pleomorphic carcinoma. Med Oncol 26(3): 287-291, 2009. PMID: 18989796. DOI: 10.1007/s12032-008-9117-4

4 Tamura Y, Fujiwara Y, Yamamoto N, Nokihara H, Horinouchi H, Kanda S, Goto Y, Kubo E, Kitahara S, Tsuruoka K, Tsuta K and Ohe Y: Retrospective analysis of the efficacy of chemotherapy and molecular targeted therapy for advanced pulmonary pleomorphic carcinoma. BMC Res Notes 8: 800, 2015. PMID: 26682906. DOI: 10.1186/s13104-015-1762-z

5 Reck M, Rodríguez-Abreu D, Robinson AG, Hui R, Csőszi T, Fülöp A, Gottfried M, Peled N, Tafreshi A, Cuffe S, O'Brien M, Rao S, Hotta K, Leiby MA, Lubiniecki GM, Shentu Y, Rangwala R, Brahmer JR and KEYNOTE-024 Investigators: Pembrolizumab versus chemotherapy for PD-L1-positive nonsmall-cell lung cancer. N Engl J Med 375(19): 1823-1833, 2016. PMID: 27718847. DOI: 10.1056/NEJMoa1606774

6 Gandhi L, Rodríguez-Abreu D, Gadgeel S, Esteban E, Felip E, De Angelis F, Domine M, Clingan P, Hochmair MJ, Powell SF, Cheng SY, Bischoff HG, Peled N, Grossi F, Jennens RR, Reck M, Hui R, Garon EB, Boyer M, Rubio-Viqueira B, Novello S, Kurata T, Gray JE, Vida J, Wei Z, Yang J, Raftopoulos H, Pietanza MC, Garassino MC and KEYNOTE-189 Investigators: Pembrolizumab plus chemotherapy in metastatic non-small-cell lung cancer. N Engl J Med 378(22): 2078-2092, 2018. PMID: 29658856. DOI: $10.1056 /$ NEJMoa 1801005

7 Socinski MA, Jotte RM, Cappuzzo F, Orlandi F, Stroyakovskiy D, Nogami N, Rodríguez-Abreu D, Moro-Sibilot D, Thomas CA, Barlesi F, Finley G, Kelsch C, Lee A, Coleman S, Deng Y, Shen Y, Kowanetz M, Lopez-Chavez A, Sandler A, Reck M and IMpower150 Study Group: Atezolizumab for first-line treatment of metastatic nonsquamous NSCLC. N Engl J Med 378(24): 22882301, 2018. PMID: 29863955. DOI: 10.1056/NEJMoa1716948

8 Kanazu M, Uenami T, Yano Y, Nakatsubo S, Hosono Y, Ishijima M, Akazawa Y, Yamaguchi T, Urasaki K, Mori M and Yokota S: Case series of pleomorphic carcinomas of the lung treated with nivolumab. Thorac Cancer 8(6): 724-728, 2017. PMID: 28881488. DOI: $10.1111 / 1759-7714.12505$

9 Kodama K, Maniwa T, Kimura Y, Yagi Y, Yamamoto Y, Ohkawa T, Takeda M, Kishima H, Koh G and Toyofuku T: Concurrent combination of irradiation and immune checkpoint inhibitor for recurrent pleomorphic carcinoma of the lung. Int Cancer Conf J 7(2): 43-47, 2017. PMID: 31149513. DOI: 10.1007/s13691-017-0315-9

10 Yoshimura A, Takumi C, Tsuji T, Hamashima R, Shiotsu S, Yuba $\mathrm{T}$, Urata $\mathrm{Y}$ and Hiraoka N: Pulmonary pleomorphic carcinoma with pseudoprogression during nivolumab therapy and the usefulness of tumor markers: A case report. Clin Case Rep 6(7): 1338-1341, 2018. PMID: 29988633. DOI: 10.1002/ccr3.1627

11 Senoo S, Ninomiya T, Makimoto G, Nishii K, Kano H, Watanabe H, Hata Y, Kubo T, Tanaka T, Hotta K, Maeda Y and Kiura K: Rapid and long-term response of pulmonary pleomorphic carcinoma to nivolumab. Intern Med 58(7): 985-989, 2019. PMID: 30568113. DOI: 10.2169/internalmedicine.0890-18

12 Okauchi S, Sasatani Y, Shiozawa T, Yamada H, Miyazaki K, Takayashiki N and Satoh H: Combination of pembrolizumab with platinum-containing chemotherapy for pleomorphic carcinoma of the lung. In Vivo 34(3): 1439-1443, 2020. PMID: 32354943. DOI: 10.21873 /invivo. 11926

13 Borghaei H, Paz-Ares L, Horn L, Spigel DR, Steins M, Ready NE, Chow LQ, Vokes EE, Felip E, Holgado E, Barlesi F, Kohlhäufl M, Arrieta O, Burgio MA, Fayette J, Lena H, Poddubskaya E, Gerber DE, Gettinger SN, Rudin CM, Rizvi N, Crinò L, Blumenschein GR Jr, Antonia SJ, Dorange C, Harbison CT, Graf Finckenstein F and Brahmer JR: Nivolumab versus docetaxel in advanced nonsquamous non-small-cell lung cancer. N Engl J Med 373(17): 1627-1639, 2015. PMID: 26412456. DOI: 10.1056/NEJMoa1507643

14 Brahmer J, Reckamp KL, Baas P, Crinò L, Eberhardt WE, Poddubskaya E, Antonia S, Pluzanski A, Vokes EE, Holgado E, Waterhouse D, Ready N, Gainor J, Arén Frontera O, Havel L, Steins M, Garassino MC, Aerts JG, Domine M, Paz-Ares L, Reck M, Baudelet C, Harbison CT, Lestini B and Spigel DR: Nivolumab versus docetaxel in advanced squamous-cell nonsmall-cell lung cancer. N Engl J Med 373(2): 123-135, 2015. PMID: 26028407. DOI: 10.1056/NEJMoa1504627

15 Chang YL, Yang CY, Lin MW, Wu CT and Yang PC: High coexpression of PD-L1 and HIF-1 $\alpha$ correlates with tumour necrosis in pulmonary pleomorphic carcinoma. Eur J Cancer 60: 125-135, 2016. PMID: 27107327. DOI: 10.1016/j.ejca.2016.03.012

16 Kim S, Kim MY, Koh J, Go H, Lee DS, Jeon YK and Chung DH: Programmed death-1 ligand 1 and 2 are highly expressed in pleomorphic carcinomas of the lung: Comparison of sarcomatous and carcinomatous areas. Eur J Cancer 51(17): 2698-2707, 2015. PMID: 26329973. DOI: 10.1016/j.ejca.2015.08.013

17 Lee J, Choi Y, Jung HA, Lee SH, Ahn JS, Ahn MJ, Park K and Sun JM: Outstanding clinical efficacy of PD-1/PD-L1 inhibitors for pulmonary pleomorphic carcinoma. Eur J Cancer 132: 150158, 2020. PMID: 32371248. DOI: 10.1016/j.ejca.2020.03.029

18 Rizvi NA, Hellmann MD, Snyder A, Kvistborg P, Makarov V, Havel JJ, Lee W, Yuan J, Wong P, Ho TS, Miller ML, Rekhtman N, Moreira AL, Ibrahim F, Bruggeman C, Gasmi B, Zappasodi R, Maeda Y, Sander C, Garon EB, Merghoub T, Wolchok JD, Schumacher TN and Chan TA: Cancer immunology. Mutational landscape determines sensitivity to PD-1 blockade in non-small cell lung cancer. Science 348(6230): 124-8, 2015. PMID: 25765070. DOI: $10.1126 /$ science.aaa1348

19 Dronca RS, Liu X, Harrington SM, Chen L, Cao S, Kottschade LA, McWilliams RR, Block MS, Nevala WK, Thompson MA, Mansfield AS, Park SS, Markovic SN and Dong H: T cell Bim levels reflect responses to anti-PD-1 cancer therapy. JCI Insight 1(6): e86014, 2016. PMID: 27182556. DOI: 10.1172/jci.insight. 86014

20 Bocanegra A, Fernandez-Hinojal G, Zuazo-Ibarra M, Arasanz H, Garcia-Granda MJ, Hernandez C, Ibañez M, Hernandez-Marin B, Martinez-Aguillo M, Lecumberri MJ, Fernandez de Lascoiti 
A, Teijeira L, Morilla I, Vera R, Escors D and Kochan G: PD$\mathrm{L} 1$ expression in systemic immune cell populations as a potential predictive biomarker of responses to pd-11/pd-1 blockade therapy in lung cancer. Int J Mol Sci 20(7): , 2019. PMID: 30986912. DOI: 10.3390/ijms20071631

21 Inomata M, Kado T, Okazawa S, Imanishi S, Taka C, Kambara K, Hirai T, Tanaka H, Tokui K, Hayashi K, Miwa T, Hayashi R, Matsui $\mathrm{S}$ and Tobe K: Peripheral PD1-positive CD4 Tlymphocyte count can predict progression-free survival in patients with non-small cell lung cancer receiving immune checkpoint inhibitor. Anticancer Res 39(12): 6887-6893, 2019. PMID: 31810958. DOI: 10.21873/anticanres.13908

22 Kagamu H, Kitano S, Yamaguchi O, Yoshimura K, Horimoto K, Kitazawa M, Fukui K, Shiono A, Mouri A, Nishihara F, Miura Y, Hashimoto K, Murayama Y, Kaira K and Kobayashi K: CD4+ T-cell immunity in the peripheral blood correlates with response to anti-pd-1 therapy. Cancer Immunol Res 8(3): 334-344, 2020. PMID: 31871122. DOI: 10.1158/2326-6066.CIR-19-0574

23 Ando K, Hamada K, Shida M, Ohkuma R, Kubota Y, Horiike A, Matsui $\mathrm{H}$, Ishiguro T, Hirasawa Y, Ariizumi H, Watanabe M, Onoue R, Tsurutani J, Yoshimura K, Tsunoda T, Kobayashi S and Wada S: A high number of PD-L1+ CD14+ monocytes in peripheral blood is correlated with shorter survival in patients receiving immune checkpoint inhibitors. Cancer Immunol Immunother, 2020. PMID: 32757055. DOI: 10.1007/s00262-020-02686-6

24 Taniguchi Y, Tamiya A, Isa SI, Nakahama K, Okishio K, Shiroyama T, Suzuki H, Inoue T, Tamiya M, Hirashima T, Imamura $\mathrm{F}$ and Atagi S: Predictive factors for poor progressionfree survival in patients with non-small cell lung cancer treated with nivolumab. Anticancer Res 37(10): 5857-5862, 2017. PMID: 28982912. DOI: 10.21873 /anticanres.12030
25 Oya Y, Yoshida T, Kuroda H, Mikubo M, Kondo C, Shimizu J, Horio Y, Sakao Y, Hida T and Yatabe Y: Predictive clinical parameters for the response of nivolumab in pretreated advanced non-small-cell lung cancer. Oncotarget 8(61): 103117-103128, 2017. PMID: 29262550. DOI: 10.18632/oncotarget.21602

26 Mezquita L, Auclin E, Ferrara R, Charrier M, Remon J, Planchard D, Ponce S, Ares LP, Leroy L, Audigier-Valette C, Felip E, ZerónMedina J, Garrido P, Brosseau S, Zalcman G, Mazieres J, Caramela C, Lahmar J, Adam J, Chaput N, Soria JC and Besse B: Association of the lung immune prognostic index with immune checkpoint inhibitor outcomes in patients with advanced nonsmall cell lung cancer. JAMA Oncol 4(3): 351-357, 2018. PMID: 29327044. DOI: 10.1001/jamaoncol.2017.4771

27 Bagley SJ, Kothari S, Aggarwal C, Bauml JM, Alley EW, Evans TL, Kosteva JA, Ciunci CA, Gabriel PE, Thompson JC, Stonehouse-Lee S, Sherry VE, Gilbert E, Eaby-Sandy B, Mutale F, DiLullo G, Cohen RB, Vachani A and Langer CJ: Pretreatment neutrophil-to-lymphocyte ratio as a marker of outcomes in nivolumab-treated patients with advanced nonsmall-cell lung cancer. Lung Cancer 106: 1-7, 2017. PMID: 28285682. DOI: 10.1016/j.lungcan.2017.01.013

Received January 20, 2021

Revised February 8, 2021

Accepted February 92021 